\title{
Penerapan Metode Bermain Peran untuk Meningkatkan Pemahaman Siswa Terhadap Konsep Pecahan Sederhana pada Mata Pelajaran Matematika di SD Inpres I Nambaru
}

\author{
Ana Agung Made Ardani \\ SD Inpres I Nambaru, Kabupaten Parigi Moutong - Provinsi Sulawesi Tengah \\ Corresponding Author. Email: anaagungardani@yahoo.com
}

\begin{abstract}
The purpose of this study was to analyze the impact of implementing role playing methods in learning mathematics on improving learning outcomes and student activeness in the basic material of simple fractions. This research method uses classroom action research. The data source came from grade III students of SD Inpres I Nambaru, totaling 24 students. Data collection techniques through formative test results. Data analysis was performed using quantitative and qualitative analysis, then consulted with the success criteria to determine student learning completeness. Based on the results of the formative tests from the first and second cycles, it was found that students' learning completeness had increased. From the initial cycle there were only 12 students out of 24 students or $50 \%$ who completed, then increased in the first cycle to 17 students from 24 students or $71 \%$, and in the second cycle reached $100 \%$ completeness, namely 24 students completed out of 24 students. So that the conclusion obtained from this study is that the application of role playing methods in learning mathematics can improve learning outcomes and student activeness in the basic material of simple fractions.
\end{abstract}

\begin{abstract}
Abstrak: Tujuan dari penelitian ini adalah untuk menganalisis dampak penerapan metode bermain peran dalam pembelajaran matematika terhadap peningkatan hasil belajar dan keaktifan siswa pada materi dasar pecahan sederhana. Metode penelitian ini menggunakan penelitian tindakan kelas. Sumber data berasal dari siswa kelas III SD Inpres I Nambaru yang berjumlah 24 siswa. Teknik pengumpulan data melalui hasil tes formatif. Analisis data dilakukan dengan menggunakan analisis kuantitatif dan kualitatif, selanjutnya dikonsultasikan dengan kriteria keberhasilan untuk mengetahui ketuntasan belajar siswa. Berdasarkan hasil tes formatif dari siklus pertama dan kedua didapatkan ketuntasan belajar siswa yang meningkat. Dari siklus awal hanya ada 12 siswa dari 24 siswa atau 50\% yang tuntas, kemudian meningkat pada siklus pertama menjadi 17 siswa dari 24 siswa atau 71\%, dan pada siklus kedua mencapai ketuntasan $100 \%$ yaitu ada 24 siswa yang tuntas dari 24 siswa. Sehingga kesimpulan yang diperoleh dari penelitian ini adalah penerapan metode bermain peran dalam pembelajaran Matematika mampu meningkatkan hasil belajar dan keaktifan siswa pada materi dasar pecahan sederhana.
\end{abstract}

\author{
Article History \\ Received: 29-01-2021 \\ Revised: 09-03-2021 \\ Published: 04-04-2021
}

Key Words:

Role Playing Methods, Learning Outcomes, Student Activity, Mathematics.

\section{Sejarah Artikel}

Diterima: 29-01-2021

Direvisi: 09-03-2021

Diterbitkan: 04-04-2021

\section{Kata Kunci:}

Metode Bermain Peran, Hasil Belajar, Keaktifan Siswa, Matematika.

How to Cite: Made Ardani, A. (2021). Penerapan Metode Bermain Peran untuk Meningkatkan Pemahaman Siswa Terhadap Konsep Pecahan Sederhana pada Mata Pelajaran Matematika di SD Inpres I Nambaru. Jurnal Paedagogy, 8(2). doi:https://doi.org/10.33394/jp.v8i2.3483

https://doi.org/10.33394/jp.v8i2.3483

This is an open-access article under the CC-BY-SA License.

\section{Pendahuluan}

Matematika merupakan ilmu dasar yang harus dikembangkan dan dipelajari oleh semua siswa, matematika sangat diperlukan dalam berbagai bidang, dari pertukangan, perdagangan, perindustrian, perkantoran bahkan jual beli dipasar tradisionalpun menggunakan matematika, tidak ada satu bidangpun didunia ini yang bisa terlepas dari perhitungan matematika, tetapi yang menjadi permasalahan disini justru matematika 
merupakan pelajaran yang tidak disukai sebagian besar siswa, matematika dianggap sebagai mata pelajaran yang sangat sulit (Siregar, 2017: Yuliati, 2018: Heryekti, 2021).

Di dalam kelas, masalah besar untuk guru-guru dan siswa-siswa dalam pembelajaran matematika salah satunya adalah motivasi. Guru berharap supaya setiap siswa menggunakan kemauan dan waktunya selama di sekolah, sehingga tujuan belajar dapat tercapai secara maksimum. Tanpa disadari oleh siswa itu sendiri, berusaha menggunakan potensi yang ia miliki sehingga tumbuh secara cepat seiring dengan perkembangan bakat mereka. Sayangnya tujuan guru sering berbeda dengan apa yang ada di dalam diri siswa, sehingga motivasi tidak berkembang melainkan terabaikan. Pertanyaannya, bagaimana membujuk siswa untuk dapat berusaha mengembangkan motivasi? Hal ini tidaklah mudah untuk dijawab, karena setiap siswa mempunyai minat, bakat, potensi, kemauan dan keterampilan yang berbeda. Oleh karena itu, mereka membutuhkan metode, tehnik-tehnik dan penanganan yang berbeda pula. Misalkan pada materi yang akan disampaikan, guru harus merencanakan mata pelajaran sebaik mungkin, yang kira-kira membuat siswa berminat tinggi terhadap pelajaran. Jika kita tidak peduli terhadap pelajaran, bagaimana kita berharap dapat memotivasi siswa kita untuk belajar?.

Motivasi berperan sebagai sasaran sekali alat untuk berprestasi yang lebih tinggi. Apabila ada persoalan yang muncul dalam proses penelitian maka dicatat oleh teman guru yang lain. Pencetusan gagasan ini adalah dari guru sendiri yang memandang ada kejanggalan dalam proses pembelajaran yang terjadi di kelasnya sendiri maupun kelas yang lain pada umumnya. Jadi penelitian merupakan pencetus inovasi, maka di sini guru mengambil Penelitian Tindakan Kelas. Guru sebagai fasilitator dalam kegiatan pembelajaran harus mampu menciptakan situasi dan iklim pembelajaran yang bersifat menyenangkan (joyful) bukan menegangkan dan menakutkan. Juga mampu menciptakan suasana demokratis, sehingga siswa terlepas dari beban mencekam, sebaiknya siswa mempunyai keberanian berekplorasi dalam penemuan dan pemecahan masalah. Peneliti sebagai seorang guru sudah berusaha semampunya dapat menjadi fasilitator pembelajaran yang baik, namun hasilnya belum memuaskan. Tujuan pembelajaran yang telah ditetapkan belum mencapai kriteria yang ditentukan, yaitu $85 \%$ siswa mencapai tuntas belajar. Buktinya pada studi pendahuluan yang telah dilakukan pada mata pelajaran Matematika pokok bahasan Pecahan Sederhana di siswa kelas III SD Inpres I Nambaru, hasilnya dari 24 siswa hanya ada 12 siswa yang mencapai tuntas belajar atau 50\% saja yang mendapat nilai 70 ke atas (sesuai KKM).

Berbekal pengalaman tersebut, telah dilakukan proses identifikasi permasalahan yang terjadi dalam kegiatan pembelajaran selama ini yang hasilnya adalah; (1) Daya serap siswa terhadap materi pelajaran masih rendah; dan (2) Keaktifan siswa selama kegiatan pembelajaran belum optimal. Berdasarkan hasil identifikasi masalah tersebut ditemukan beberapa faktor penyebab mengapa minat dan hasil belajar siswa dalam pembelajaran matematika rendah, hal tersebut menyebabkan siswa sulit dalam memahami mata pelajaran matematika tentang Pecahan Sederhana. Faktor penyebabnya adalah sebagai berikut; (1) Topik atau materi pelajaran yang diberikan guru kurang menarik dipelajari siswa; (2) Metode yang digunakan guru dalam menyampaikan materi kurang bervariasi; (3) Keterbatasan media yang dimiliki sekolah; dan (4) Guru kurang memberikan penguatan atau pujian atas prestasi akademik dan tingkah laku sosial mereka.

Gambaran permasalahan diatas menunjukkan bahwa pembelajaran matematika perlu diperbaiki guna meningkatkan keaktifan dan hasil belajar siswa. Usaha tersebut diawali dengan penerapan metode belajar yang tepat yang dapat merangsang siswa untuk aktif saling berbagi ide, mendorong siswa untuk bekerjasama, dan menyenangkan supaya mampu 
menciptakan iklim pembelajaran yang kondusif yang pada akhirnya akan meningkatkan aktivitas dan hasil belajar siswa. Untuk mengatasi masalah di atas maka perlu diusahakan metode pembelajaran yang tepat (Gita, Rizka, Zinnurain, 2021).

Dari metode pembelajaran yang ada, yang menarik dan menyenangkan serta mampu meningkatkan keaktifan siswa salah satunya yaitu melalui metode bermain peran (role playing). Metode bermain peran adalah suatu cara mengajar dengan melibatkan siswa secara langsung untuk memainkan peran seorang tokoh dengan segala improfisasi dan keahliannya (Depdiknas, 2003; Rabiah, 2020; Ayu \& Syarafuddin, 2018). Tujuan dari metode bermain peran adalah untuk menempuh keberanian dan menghayati gambaran lebih realistik dari meteri pelajaran. Adapun tujuan dari penelitian ini adalah untuk menganalisis dampak penerapan metode bermain peran dalam pembelajaran matematika terhadap peningkatan hasil belajar dan keaktifan siswa pada materi dasar pecahan sederhana di kelas III SD Inpres I Nambaru.

\section{Metode Penelitian}

Penelitian ini menggunakan metode penelitian tindakan kelas (PTK). Penelitian tindakan kelas adalah penelitian tindakan yang dilakukan oleh guru dengan tujuan untuk memperbaiki mutu pelaksanaan pembelajaran di kelasnya (Suparno, 2008). Selain itu menurut Arikunto dkk (2016), PTK merupakan suatu pencermatan terhadap kegiatan pembelajaran berupa sebuah tindakan, yang sengaja dimunculkan dan terjadi dalam sebuah kelas secara bersamaan. Dengan demikian, PTK berfokus pada proses belajarmengajar yang terjadi di kelas dan dilakukan pada situasi yang sebenarnya (alami). Penelitian dilaksanakan dalam dua siklus, tiap siklus terdiri dari empat tahap yaitu: perencanaan, pelaksanaan tindakan, observasi, analisis dan refleksi yang mengacu pada desain penelitian model Kemmis dan Taggart (dalam Suharsimi, 2008).

Penelitian ini dilaksanakan di SD Inpres I Nambaru pada materi dasar pecahan sederhana mata pelajaran matematika. Subyek dalam penelitian ini adalah siswa kelas kelas III SD Inpres I Nambaru yang berjumlah 24 siswa. Instrumen penelitian yang digunakan pada penelitian ini terdiri dari Lembar Pengamatan, tes akhir materi, dan angket respon siswa. Untuk mengetahui adanya perbaikan dalam proses dan hasil belajar sesuai dengan tujuan penelitian diperlukan indikator. Indikator yang digunakan untuk mengukur peningkatan hasil belajar siswa adalah keterlibatan siswa secara aktif dalam proses pembelajaran (Mariani, 2020; Wahyuningsih, 2019). Indikator yang digunakan untuk mengukur peningkatan kemampuan daya ingat terhadap pembelajaran dengan ketuntasan siswa mempelajari materi. Kriteria siswa dinyatakan tuntas belajar adalah jika telah mencapai tingkat penguasaan materi $70 \%$ ke atas yang ditunjukkan dengan perolehan nilai formatif 70 atau lebih (sesuai KKM). Keberhasilan upaya perbaikan pembelajaran dengan kriteria sebagai berikut; (1) Proses perbaikan pembelajaran (peningkatan keterlibatan belajar siswa) dinyatakan berhasil jika $85 \%$ dari jumlah siswa terlibat aktif selama proses pembelajaran berlangsung; dan (2) Proses perbaikan pembelajaran (peningkatan daya ingat siswa terhadap materi pembelajaran) dinyatakan berhasil jika $85 \%$ dari jumlah siswa tuntas dalam belajar dengan perolehan nilai formatif 70 atau lebih (KKM).

\section{Hasil Penelitian dan Pembahasan}

Pelaksanaaan kegiatan perbaikan pembelajaran kelas III mata pelajaran matematika pokok bahasan membandingkan pecahan menggunakan metode bermain peran, melalui dua siklus, hasilnya dapat diketahui sebagai berikut : 


\section{Deskripsi Siklus I}

Setelah intervensi dilakukan, dapat dilihat terjadi perubahan yang berarti di semua faktor, walau belum mencapai batas kriteria yang telah ditetapkan. Hal ini dapat dilihat dari dari data hasil perencanaan, pelaksanaan, pengamatan, dan refleksi. Pada tahap perencanan, data yang diperoleh berupa : rencana pelaksanaan perbaikan pembelajaran (RPPP) yang di dalamnya tercakup komponen skenario pembelajaran yang akan diimplementasikan; seperangkat instrumen yang akan digunakan untuk pengumpulan data; dan data pendukung pembelajaran berupa lembar kerja siswa (LKS).

Pada tahap pelaksanaan tindakan, data yang diperoleh berupa rekepitulasi nilai tes formatif pembelajaran, yakni; (1) Pada studi awal nilai rata-rata kelas 67,70 setelah dilakukan perbaikan mengalami kenaikan mejadi 72,29. rata-rata kelas naik 4,59. (2) Ada 17 siswa yang mengalami kenaikan prestasi $(71 \%)$. (3) Jumlah siswa yang telah mencapai tingkat ketuntasan belajar 17 anak (71\%). Hasil observasi pada siklus I diperoleh gambaran tentang keaktifan siswa selama proses pembelajaran. Perhatian siswa tidak semuanya terpusat pada pelajaran, keterlibatan siswa juga terlihat tidak begitu terasa, siswa terlihat pasif dan hanya beberapa siswa yang terlihat mampu mengkomunikasikan materi yang diajarkan, namun terjadi peningkatan keaktifan belajar jika dibanding studi awal. Hasil yang didapat bisa digambarkan pada nilai rata-rata siswa yang meningkat dari 67,70 menjadi 72,29 . Angka tersebut menunjukkan adanya peningkatan keaktifan siswa selama pembelajaran.

Data hasil refleksi menunjukkan; (1) Ketika siswa mulai diberi arahan cara bermain peran sebagian siswa sesekali tertawa malu-malu, dan ada yang menyembunyikan mukanya karena takut ditunjuk, sementara guru melanjutkan penjelasannya. (b) Ketika pembagian kelompok berlangsungkelas menjadi ribut. (3) Ketika peragaan dimulai, terjadi keributan kecil karena sebagian siswa menertawakan temannya yang maju ke depan. (4) Dari 8 siswa yang berhasil dimintai komentarnya 5 siswa yang mengatakan sangat membantu, 1 siswa tidak memberikan komentar apapun dan 2 siswa mengatakan tidak.

Berdasarkan data yang terkumpul dan data hasil diskusi peneliti melakukan penelaahan dan mencoba menyimpulkan hasil tindakan yang telah dilakukan. Kesimpulan ini menunjukkan bahwa penguasaan siswa sudah meningkat, meski belum optimal (17 dari 24 siswa sudah mencapai tingkat ketuntasan belajar. Masih banyak anak-anak yang ingin memainkan peran tetapi tidak memperoleh kesempatan. Baru $60 \%$ dari siswa yang menunjukkan keaktifan dalam mengikuti pembelajaran.

\section{Deskripsi Siklus II}

Setelah mengakomodasi masukan dari siklus I, dalam pelaksanaan perbaikan siklus II, saya berusaha menyempurnakan tindakan. Dalam siklus II ini, alternatif pemecahan masalah dengan optimalisasi bermain peran semakin terasa lebih baik. Hasil ini terlihat dari data perencanaan, pelaksanaan, pengamatan dan refleksi. Pada tahap perencanan tindakan, data yang diperoleh berupa : Rencana Pelaksanaan Perbaikan Pembelajaran (RPPP) siklus II yang dibuat dengan tambahan sesuai perubahan-perubahan perbaikan setelah mengakomodasi masukan dari siklus I, seperangkat instrumen yang akan digunakan dalam pengumpulan data, dan data pendukung pembelajaran berupa lembar kerja LKS.

Pada tahap pelaksanaan tindakan, data yang diperoleh berupa Hasil tes formatif pembelajaran yakni; (1) Pada siklus I nilai rata-rata kelas 72,29 setelah dilakukan perbaikan mengalami kenaikan mejadi 80,42. rata-rata kelas naik 8,13. (2) Ada 24 siswa yang mengalami kenaikan prestasi (100\%). (3) Jumlah siswa yang telah mencapai tingkat ketuntasan belajar 24 anak (100\%). Hasil observasi pada siklus kedua diperoleh gambaran tentang keaktifan siswa selama proses pembelajaran. perhatian siswa mulai terpusat pada 
pelajaran. Keterlibatan siswa baik secara individu maupun kelompok cukup terlihat baik, ada beberapa siswa yang berani bertanya tanpa disuruh. Pembentukan kelompok belajar untuk melakukan bermain peran cukup memberikan warna keaktifan dan keterlibatan bagi siswa selama proses pembelajaran. Hasil yang didapat bisa digambarkan pada nilai rata-rata siswa yang meningkat mencapai 80,42 . Angka tersebut menunjukkan peningkatan keaktifan siswa selama pembelajaran.

Data hasil refleksi menunjukkan bahwa; (1) Pembelajaran berlangsung sangat kondusif dan interaktif. Siswa tampak senang belajar. Hal ini tampak dari kesungguhan siswa dalam melaksanakan tugas yang diberikan guru. (2) Jumlah siswa yang tuntas sudah jauh melampaui kriteria yang ditetapkan bahkan mencapai angka 100\%. (3) Dari 8 siswa yang dimintai komentarnya, seluruhnya mengatakan sangat membantu mereka dalam memahami materi. Berdasarkan data yang terkumpul dan data hasil diskusi peneliti melakukan penelaahan dan mencoba menyimpulkan hasil tindakan yang telah dilakukan. Kesimpulan ini menunjukkan bahwa penguasaan siswa sudah meningkat (24 dari 24 siswa sudah mencapai tingkat ketuntasan belajar).

Hasil kegiatan perbaikan pembelajaran Matematika di kelas III SD Inpres I Nambaru dengan materi pokok Pecahan Sederhana dengan menggunakan metode Bermain Peran dilaksanakan dalam dua siklus dapat dilaporkan sebagai berikut.

Tabel 1. Rekapitulasi Ketuntasan Belajar Siswa pada Setiap Siklus

\begin{tabular}{|c|c|c|c|c|c|c|}
\hline \multirow{2}{*}{ No } & Pembelajaran & $\begin{array}{c}\text { Nilai } \\
\text { rata- } \\
\text { rata } \\
\text { Kelas }\end{array}$ & Tuntas Persentase & Belum & Persentase \\
\hline 1 & Studi Awal & 67,70 & 12 & $50 \%$ & 12 & $50 \%$ \\
\hline 2 & Siklus I & 72,29 & 17 & $71 \%$ & 7 & $29 \%$ \\
\hline 3 & Siklus II & 80,42 & 24 & $100 \%$ & 0 & $0 \%$ \\
\hline
\end{tabular}

Dari tabel di atas dapat diperoleh keterangan sebagai berikut :

1) Pada siklus I, angka ketuntasan siswa naik $21 \%$ (bertambah 5 siswa dari studi awal)

2) Pada siklus II, angka ketuntasan siswa naik $29 \%$ (bertambah 7 siswa dari siklus I)

3) Pada siklus I, nilai rata-rata kelas mengalami kenaikan sebesar 4,59.

4) Pada siklus II, nilai rata-rata kelas mengalami kenaikan sebesar 8,13 dari siklus I (atau bertambah 12,72 dari studi awal)

Untuk lebih jelasnya peningkatan ketuntasan belajar siswa dan nilai rata-rata kelas dapat dilihat pada gambar diagram batang berikut ini :

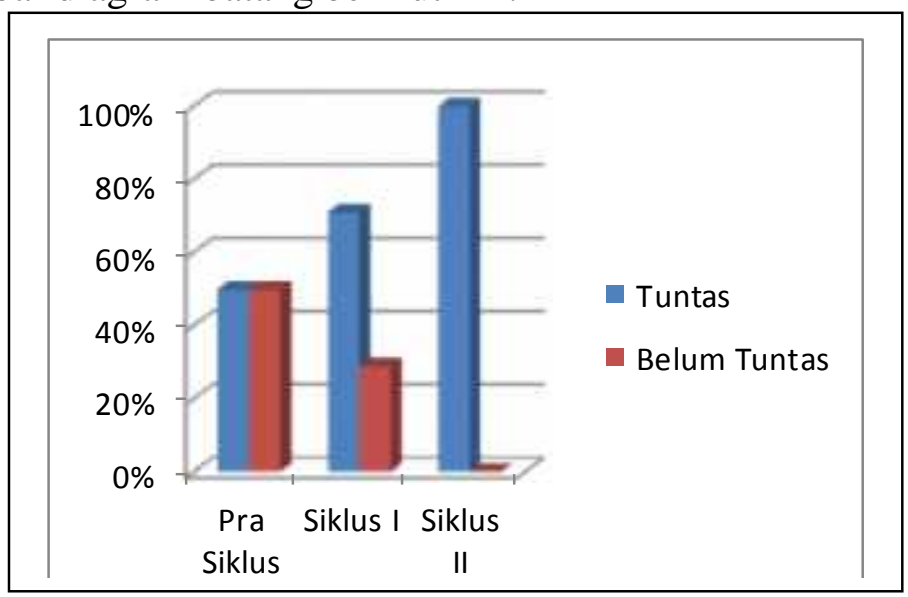


Alternatif pemecahan masalah untuk mengatasi rendahnya pemahaman siswa terhadap konsep Pecahan Sederhana dan rendahnya minat belajar siswa dengan menggunakan metode bermain peran pada pembelajaran Matematika konsep Pecahan Sederhana di kelas III SD Inpres I Nambaru, Kota Jambi ternyata memberikan kenaikan hasil belajar dan keaktifan belajar yang signifikan jika dibandingkan dengan studi sebelumnya. Berkat intervensi ini ada kenaikan ketuntasan sebesar $21 \%$, dan kenaikan nilai rata-rata sebesar 4,59. Hal ini seperti yang dikatakan Krapp, Hidi dan Reeminger (dalam Mikarsa, dkk., 2007) Minat merupakan dorongan dari dalam diri seseorang atau faktor yang menimbulkan ketertarikan atau perhatian secara selektif, yang menyebabkan dipilihnya suatu objek yang menguntungkan, menyenangkan, dan lama-kelamaan akan mendatangkan kesungguhan dan kepuasan bagi dirinya. Lebih lanjut Mikarsa dkk (2007) mengatakan "Seorang anak tidak lahir dengan minat tertentu. Minat berkembang melalui pengalaman belajar. Seorang guru harus dapat menumbuhkan minat anak agar perkembangan minatnya sejalan dengan meluasnya cakrawala mental anak. Intervensi yang peneliti lakukan dengan mengimplementasikan metode bermain peran dalam pembelajaran aktif ternyata menimbulkan ketertarikan bagi anak sehingga berimplikasi pada kesungguhan belajar yang akhirnya ternyata berkorelasi positif dengan peningkatan pemahaman dan peningkatan hasil belajar siswa. Di samping itu, penggunan metode bermain peran telah mampu mempermudah siswa dalam belajar.

Setelah dilakukan intervensi terhadap kelemahan hasil refleksi pada siklus I, melalui pengaturan mengubah posisi tempat duduk membentuk tapal kuda (U) kenaikan ketuntasan belajar siswa semakin terlihat. Kenaikan ketuntasan belajar sebesar 29\%, dan kenaikan nilai rata-rata 8,13. Hal ini sudah sesuai dengan apa yang dikatakan Trihartanto (2007), "Setiap media sudah pasti memiliki kelebihan dan kekurangan. Untuk mempermudah hasil yang optimal, pemilihan media di antaranya perlu memperhatikan jumlah siswa atau besar kecilnya kelas". Faktor lain yang turut memberikan kontribusi terhadap peningkatan hasil adalah dengan diberikannya kesempatan kepada siswa untuk melakukan ikut aktif bermain peran.

\section{Kesimpulan}

Kesimpulan yang diperoleh dari penelitian ini antara lain adalah; (1) Penerapan metode bermain peran dalam pembelajaran matematika pokok bahasan pecahan sederhana pada siswa kelas III SD Inpres I Nambaru mampu meningkatkan hasil belajar siswa terhadap materi. Ditunjukkan dengan peningkatan rata-rata kelas yang semula pada pembelajaran awal 67,70 meningkat menjadi 72,29 pada siklus I, dan meningkat lagi menjadi 80,42 pada siklus II. (2) Penerapan metode bermain peran dalam pembelajaran matematika pokok bahasan pecahan sederhana siswa kelas III SD Inpres I Nambaru mampu meningkatkan keaktifan siswa dalam belajar terhadap materi. Pada Pembelajaran awal siswa yang pasif meningkat menjadi $60 \%$ siswa aktif pada siklus I, dan meningkat menjadi $85 \%$ pada siklus II.

\section{Saran}

Adapun saran yang dapat disampaikan berdasarkan hasil penelitian ini adalah bagi guru lainnya agar dapat berkreasi dan melakukan modifikasi dalam penerapan metode bermain peran ini agar hasil belajar siswa dapat tercapai dengan lbih maksimal, disamping pemanfaatan dukungan penggunaan media belajar lainnya.

\section{Daftar Pustaka}

Arikunto, S, Sukardjono, P Supardi. (2016). Penelitian Tindakan Kelas. Jakarta: Bumi Aksara. 
Arikunto, Suharsimi. (2009). Dasar-Dasar Evaluasi Pendidikan. Jakarta: PT. Bina Aksara

Ayu Maningrum, R., \& Syarafuddin, H. (2018). Pengaruh Teknik Role Playing Terhadap Kecemasan Belajar pada Siswa Kelas VIII di SMPN 2 Praya. Jurnal Kependidikan: Jurnal Hasil Penelitian dan Kajian Kepustakaan di Bidang Pendidikan, Pengajaran dan Pembelajaran, 4(2), 198-205. doi:https://doi.org/10.33394/jk.v4i2.1130

Heryekti Pujingsih, R. (2021). Meningkatkan Motivasi dan Hasil Belajar Matematika dengan Metode Kooperatif Tipe Jigsaw di SMA Negeri 1 Gerung. Jurnal Paedagogy, 8(1), 50-56. doi:https://doi.org/10.33394/jp.v8i1.3196

Mariani Artini, N. (2020). PEMBELAJARAN MODEL STAD UNTUK MENINGKATKAN PRESTASI BELAJAR MATEMATIKA PADA SISWA KELAS V SDN 39 CAKRANEGARA. Jurnal $\quad$ Paedagogy, 30-37. doi:https://doi.org/10.33394/jp.v3i1.3033

Mikarsa, HL., Taufik, A., Prianto, P.L. (2007) Pendidikan Anak Usia SD. Jakarta: Universitas Terbuka.

Rabiah, R. (2020). PENGARUH BERMAIN PERAN TERHADAP KEMAMPUAN SOSIAL EMOSIONAL ANAK USIA 5-6 TAHUN DI TK AISYIYAH BUSTANUL ATHFAL 5 MATARAM. Jurnal Paedagogy, 1(1), 28-34. doi:https://doi.org/10.33394/jp.v1i1.3056

Sumantri. Dan Syaodih, N.(2016). Perkembangan Peserta Didik. Jakarta: Universitas Terbuka.

Siregar, N. R. (2017). Persepsi siswa pada pelajaran matematika: studi pendahuluan pada siswa yang menyenangi game. Prosiding Temu Ilmiah Nasional X Ikatan Psikologi Perkembangan Indonesia, 1.

Suarni, G., Rizka, M., \& Zinnurain, Z. (2021). Analisis Pengaruh Penerapan Model Pembelajaran Sains Teknologi Masyarakat Terhadap Hasil Belajar Siswa. Jurnal Paedagogy, 8(1), 31-38. doi:https://doi.org/10.33394/jp.v8i1.3226

Suparno, Paul. (2008). Riset Tindakan untuk Pendidikan. Jakarta: PT Gramedia Widia Sarana Indonesia.

Trihartanto, S.I. (2007). Media Pembelajaran Bahasa Indonesia. Makalah Disajikan dalam Workshop Pengembangan Model Pembelajaran Mapel Bahasa Indonesia dan Ilmu Pengetahuan Alam bagu Guru Sekolah Dasar provinsi jawa Tengah. LPMP jawa Tengah. Semarang, 22-31 Oktober 2007.

Wahyuningsih, W. (2019). Penerapan Metode Latihan Mandiri Untuk Meningkatkan Hasil Belajar Matematika pada Siswa SMP Negeri 1 Kayangan. Jurnal Kependidikan: Jurnal Hasil Penelitian dan Kajian Kepustakaan di Bidang Pendidikan, Pengajaran dan Pembelajaran, 5(2), 149-155. doi:https://doi.org/10.33394/jk.v5i2.1813

Winataputra Udin, S. (2007). Strategi Belajar Mengajar. Jakarta: Universitas Terbuka Yuliati, G. (2018). Peningkatan Hasil Belajar Matematika Siswa Kelas XI IPA 3 SMA Negeri 1 Batukliang Melalui Penggunaan Model Pembelajaran Student Teams Achievement Division. Jurnal Kependidikan: Jurnal Hasil Penelitian dan Kajian Kepustakaan di Bidang Pendidikan, Pengajaran dan Pembelajaran, 4(1), 31-40. doi:https://doi.org/10.33394/jk.v4i1.899 